\title{
MOLESTOWANIE SEKSUALNE I JEGO KOSZTY FINANSOWE DLA GOSPODARKI
}

\section{WPROWADZENIE}

Problematyka molestowania seksualnego jest zagadnieniem interdyscyplinarnym, które jest przedmiotem zainteresowania badań o charakterze socjologicznym, prawnym, psychologicznym, a także medycznym. Wspomniane zjawisko dotyczy również rynku pracy, co implikuje jego charakter ekonomiczny. Z tego względu molestowanie seksualne można badać i przedstawiać w perspektywie ekonomicznej. Celem głównym artykułu jest próba rozważenia molestowania seksualnego jako złożonego i interdyscyplinarnego zjawiska występujacego na rynku pracy w sferze pracy i płacy w ujęciu ekonomicznym. Za najważniejsze problemy badawcze dotyczace molestowania seksualnego uznano znalezienie odpowiedzi na następujące pytania badawcze:

- Jakie formy molestowania seksualnego - obok innych form dyskryminacji ekonomicznej - występują w sferze pracy i płacy?

- Jaki jest zakres molestowania seksualnego w Polsce?

- Jakie sa potencjalne efekty występowania molestowania seksualnego $\mathrm{w}$ pracy?

- Jakie są metody pomiaru finansowych kosztów molestowania seksualnego na poziomie mikro-, mezo- oraz makroekonomicznym?

- Jaki jest szacunkowy koszt molestowania seksualnego w miejscu pracy dla polskiej gospodarki?

Przedmiotem opracowania jest molestowanie seksualne. Zakres przestrzenny przedstawionych $\mathrm{w}$ artykule badań obejmuje Polskę, jednak ze względu na dostępność danych statystycznych dotyczaccych konsekwencji molestowania seksualnego na poziomie jednostki (mikro-), przedsiębiorstwa (mezo-) i gospodarki (makroekonomicznym) zaprezentowane będą również wyniki badań pochodzące z innych krajów, tj. z Chin, Wielkiej Brytanii, Szwecji i USA. Zakres czasowy podjętych rozważań odnosi się do lat 2007-2018. Hipoteza przyjęta w opracowaniu brzmi następująco: molestowanie seksualne w miejscu pracy przyczynia się do powstawania mierzalnych kosztów o charakterze finansowym, których ograniczenie mogłoby realnie przyczynić się do osiagania wyższego poziomu produktu krajowego brutto.

$\mathrm{W}$ artykule $\mathrm{w}$ pierwszej kolejności przedstawiono istotę i formy molestowania seksualnego oraz wpływu tego zjawiska na możliwość występowania innych rodzajów dyskryminacji ekonomicznej. Następnie dokonano analizy 
dostępnych wyników badań na temat zakresu, skutków ekonomicznych i determinant rozważanego zjawiska w Polsce, w Chinach i USA. W dalszej części przedstawiono metody dedukcyjne i indukcyjne pomiaru analizowanego zjawiska w Wielkiej Brytanii, Szwecji i USA, a także podjęto próbę oszacowania kosztów molestowania seksualnego dla Polski dla 2018 r.

\section{ISTOTA I FORMY MOLESTOWANIA SEKSUALNEGO}

W sensie ekonomicznym molestowanie seksualne jest forma dyskryminacji na rynku pracy sprowadzająca się do nieakceptowanych zachowań dotyczących płci bądź sfery seksualnej, prowadzące do negatywnych skutków w sferze pracy zawodowej, a zwłaszcza obniżenia wydajności pracy. Na molestowanie seksualne mogą składać się elementy fizyczne, werbalne i pozawerbalne ${ }^{1}$.

\section{Schemat 1}

Formy molestowania seksualnego

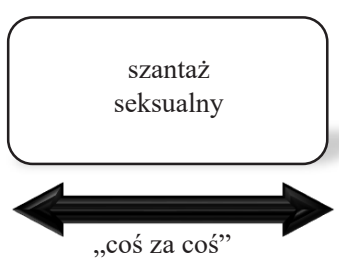

„coś za coś”

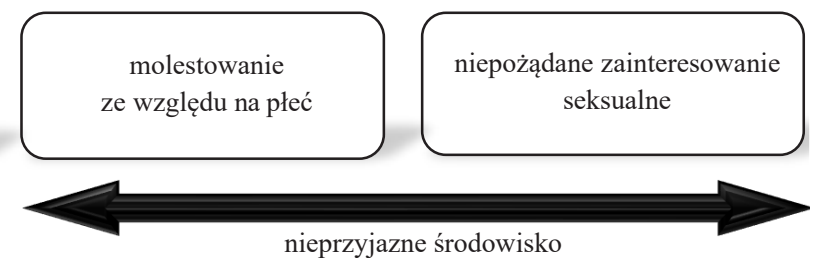

nieprzyjazne środowisko

Źródło: Fitzgerald, Gelfand, Fritz (1995): 431.

Wśród form molestowania seksualnego na rynku pracy, które przedstawia schemat 1, wyróżnić można szantaż seksualny, tzw. coś za coś (łac. quid pro $q u o$ ). Występuje on, gdy osoba molestująca ma wpływ na położenie zawodowe osoby molestowanej w miejscu pracy. Gdy molestujący decyduje o:

- przyjęciu do pracy, utrzymaniu warunków zatrudnienia osoby molestowanej; w przypadku odrzucenia propozycji seksualnej ze strony potencjalnej ofiary, może wystapić dyskryminacja zatrudnieniowa, typu human capital i rodzicielska;

- awansie zawodowym, uniknięciu przesunięcia na gorsze stanowisko, degradacji zawodowej, w analogiczny sposób sytuacja ta może przyczynić się do powstania dyskryminacji: kwalifikacyjnej i zawodowej oraz płacowej².

1 Ustawa z 26 czerwca 1974 r., t.jedn.: Dz. U. 2019, Nr 0, poz. 1040 ze. zm; ustawa z 3 grudnia 2010 r., t.jedn.: Dz. U. 2016, Nr 0, poz. 1219 ze zm..; Kalinowska-Sufinowicz (2020): 5.

2 Szerzej nt. form dyskryminacji w sferze pracy i płacy: Kalinowska-Nawrotek (2004): 231 245; Kalinowska-Sufinowicz (2013): 20. 
Podkreślenia wymaga, że każda z tych sytuacji powoduje określone konsekwencje finansowe ${ }^{3}$. W tabeli 1 przedstawiono potencjalne formy dyskryminacji ekonomicznej w zależności od etapu procesu kadrowego oraz związanych z nim czynności.

Tabela 1

Potencjalne formy dyskryminacji w zależności od etapu procesu kadrowego

\begin{tabular}{|c|c|c|}
\hline Etap & Czynności & Formy dyskryminacji \\
\hline $\begin{array}{l}\text { Przyjmowanie do } \\
\text { i zwalnianie z pracy }\end{array}$ & $\begin{array}{l}\text { - ogłoszenia o pracy } \\
\text { - rozmowa kwalifikacyjna } \\
\text { - zatrudnienie } \\
\text { - okres i warunki pracy } \\
\text { - zwolnienie }\end{array}$ & $\begin{array}{l}\text { - zatrudnieniowa } \\
\text { - samodyskryminacja } \\
\text { - rodzicielska } \\
\text { - molestowanie seksualne }\end{array}$ \\
\hline $\begin{array}{l}\text { Mobilność zawodowa } \\
\text { i podnoszenie kompe- } \\
\text { tencji }\end{array}$ & $\begin{array}{l}\text { - awans poziomy } \\
\text { - awans pionowy } \\
\text { - szkolenia } \\
\text { - programy szkoleniowe } \\
\text { - udogodnienia w firmie }\end{array}$ & $\begin{array}{l}\text { - kwalifikacyjna i zawodowa } \\
\text { - typu human capital } \\
\text { - rodzicielska } \\
\text { - samodyskryminacja } \\
\text { - molestowanie seksualne }\end{array}$ \\
\hline Ocenianie & $\begin{array}{l}\text { - przydzielanie zadań } \\
\text { - ocena pracownicza } \\
\text { - kontrola }\end{array}$ & $\begin{array}{l}\text { - samodyskryminacja } \\
\text { - rodzicielska } \\
\text { - molestowanie seksualne }\end{array}$ \\
\hline Wynagradzanie & $\begin{array}{l}\text { - płaca } \\
\text { - otrzymanie podwyżki } \\
\text { - korzyści pozapłacowe } \\
\text { - programy emerytalne i rentowe }\end{array}$ & $\begin{array}{l}\text { - płacowa } \\
\text { - molestowanie seksualne }\end{array}$ \\
\hline
\end{tabular}

Źródło: National Research Council (2004): 67; Kalinowska-Nawrotek (2004); Kalinowska-Sufinowicz (2013).

Druga z wymienionych na schemacie 1 form molestowania seksualnego jest stwarzanie nieprzyjaznych warunków pracy (ang. hostile environment), którego efektem ostatecznym jest obniżenie wydajności pracy. Klasyfikuje się tu dwa rodzaje zachowań. Po pierwsze, są to niepożądane zainteresowanie seksualne, wskazać tu można przede wszystkim zachowania zwiąane z seksualnością danej osoby. Po drugie, molestowanie, które zachodzi z uwagi na przynależność do określonej płci, niekoniecznie dotyczące seksualności, ale z powodu bycia kobietą lub mężczyzną ${ }^{4}$. Należy podkreślić, że w przypadku tworzenia wrogich warunków pracy możemy mieć do czynienia ze sprawcą lub grupą sprawców. Mogą to być pracodawca, przełożony, większa grupa osób współpracujących z osobą molestowana, jak również osoby niezatrudnione $\mathrm{w}$ danym przedsiębiorstwie, a jedynie pozostające w relacjach handlowych (np. klienci, dostawcy, petenci instytucji, przedsiębiorstwa lub

${ }^{3}$ Warylewski (1999); Kędziora (2008): 19; Hołyst (2004): 18.

${ }^{4}$ Hołyst (2004): 18. 
organizacji) $^{5}$. W efekcie niesprzyjającej atmosfery możemy mieć do czynienia z samodyskryminacja, gdy osoba molestowana rezygnuje ze starania się o awans zawodowy, udział w szkoleniu czy z dyskryminacją płacową w przypadku zaprzestania starań o podwyżkę.

\section{ZAKRES MOLESTOWANIA SEKSUALNEGO W POLSCE}

Rozważając zagadnienie występowania molestowania seksualnego w miejscu pracy, w pierwszej kolejności warto przedstawić dane statystyczne dotyczące zakresu występowania omawianego zjawiska w Polsce. Zestawienie wyników badań na ten temat według instytucji je przeprowadzającej wraz z definicjami molestowania seksualnego oraz informacjami dotyczacymi zakresu i próby zostały zamieszczone w tabeli 2 .

Dokonując konkluzji przedstawionych danych statystycznych dotyczacych molestowania seksualnego w miejscu pracy w Polsce, wypada stwierdzić, że mamy do czynienia ze znacznymi różnicami pomiędzy wynikami badań przeprowadzonymi przez różne ośrodki. Podkreślenia wymaga fakt, że podobna sytuacja dotyczy również innych krajów ${ }^{6}$. Brunon Hołyst podaje, że odsetek kobiet, które spotkały się z molestowaniem seksualnym, sięga w Polsce od kilku do $88 \%{ }^{7}$. Ze względu na niespotykany w innych zjawiskach gigantyczny margines rozbieżności warto zaprezentować przyczyny, dla których zakres molestowania seksualnego w Polsce ma niemal 86 punktów procentowych (od $2 \%$ do $88 \%$ ).

Po pierwsze, zarówno definicje, jak i klasyfikacja danego zachowania jako przejaw molestowania seksualnego nie sa jednoznaczne i występuje tu wiele sprzeczności i niejednoznaczności. Dylematy pojawiają się nie tylko wśród osób badanych - respondentek i respondentów, ale również autorów, autorek i przeprowadzajacych badanie ${ }^{8}$. U podłoża obserwowanych różnic leżą uwarunkowania kulturowe, sytuacja prawna, a także stopień uwrażliwienia i świadomości społecznej ${ }^{9}$.

Po drugie, percepcja sygnałów seksualnych przez obie płcie jest silnie zróżnicowana. Na podstawie dostępnych badań eksperymentalnych Hołyst zwraca uwagę na to, że mężczyźni częściej niż kobiety interpretują zachowania neutralne w kategoriach erotycznych, przypisujac im domniemane intencje seksualne ${ }^{10}$.

Po trzecie, określone zachowanie może być różnie interpretowane w zależności od płci. Kobiety częściej postrzegają określone zachowania jako prze-

\footnotetext{
5 Kędziora (2008): 19-20.

${ }^{6}$ Por. także Szwiec (2006): 27.

7 Hołyst (2004): 20.

8 Szwiec (2006): 26.

9 Hołyst (2004): 20.

10 Hołyst (2004): 19.
} 
kraczanie nieakceptowanych przez nie granic. Przykładem może być dotyk o podłożu seksualnym interpretowany jako molestowanie seksualne przez $84 \%$ kobiet oraz 59\% mężczyzn ${ }^{11}$. Innym jeszcze powodem rozbieżności pomiędzy wynikami osiagniętymi przez różne ośrodki badawcze jest zastosowanie odmiennych metodologii badania, co także wpływa na rezultaty. W sytuacji zadawania pytania na wysokim stopniu ogólności (Czy doświadczyłaś / eś molestowania seksualnego?), jak również małej szczegółowości badania (brak uwzględnienia i rozróżnienia istotnych obszarów molestowania seksualnego) negatywna odpowiedź może wynikać z braku świadomości na temat badanego zjawiska (np. ze względu na przekonanie, że molestowanie seksualne to jedynie gwałt lub próba dokonania gwałtu).

Tabela 2

Zestawienie wyników badań na temat molestowania seksualnego według instytucji realizującej w Polsce w latach 2007-2018

\begin{tabular}{|l|l|l|l|}
\hline $\begin{array}{c}\text { Instytucja } \\
\text { /rok badania }\end{array}$ & \multicolumn{1}{|c|}{$\begin{array}{c}\text { Definicja molestowania } \\
\text { seksualnego }\end{array}$} & $\begin{array}{c}\text { Zakres występo- } \\
\text { wania }\end{array}$ & $\begin{array}{c}\text { Zasięg badania/ } \\
\text { Liczebność próby }\end{array}$ \\
\hline $\begin{array}{l}\text { CBOS } \\
\text { /2007 }\end{array}$ & $\begin{array}{l}\text { Nieakceptowane zachowania } \\
\text { o podłożu seksualnym }\end{array}$ & $2 \%-41 \%$ & $\begin{array}{l}\text { Polska/ } \\
922 \text { (kobiety } \\
\text { i mężczyźni) }\end{array}$ \\
\hline $\begin{array}{l}\text { STER } \\
\text { /2015 }\end{array}$ & $\begin{array}{l}\text { Forma przemocy seksualnej } \\
\text { w miejscu pracy i w miejscach } \\
\text { publicznych }\end{array}$ & $87,6 \%$ & $\begin{array}{l}\text { Województwa: pod- } \\
\text { karpackie, pomor- } \\
\text { skie, mazowieckie/ } \\
451 \text { (kobiety) }\end{array}$ \\
\hline $\begin{array}{l}\text { CBOS } \\
\text { /2017 }\end{array}$ & $\begin{array}{l}\text { Formy: publiczne wyrażanie } \\
\text { podziwu dla kobiecych części } \\
\text { ciała; uporczywe wpatrywa- } \\
\text { nie się; składanie propozycji } \\
\text { seksualnych; celowe dotknięcie } \\
\text { z podtekstem seksualnym }\end{array}$ & $15 \%-65 \%$ & $\begin{array}{l}\text { Polska/ } \\
948 \text { (kobiety } \\
\text { i mężczyźni) }\end{array}$ \\
\hline $\begin{array}{l}\text { Każde zachowanie o charakte- } \\
\text { /2018 }\end{array}$ & $\begin{array}{l}\text { nze seksualnym nieakceptowa- } \\
\text { do której się odnosi, naruszają- } \\
\text { ce jej godność }\end{array}$ & $2 \%-49 \%$ & $\begin{array}{l}\text { Polska/ } \\
989 \text { (kobiety } \\
\text { i mężczyźni) }\end{array}$ \\
\hline $\begin{array}{l}\text { Nieakceptowane zachowania } \\
\text { /2018 }\end{array}$ & $\begin{array}{l}\text { o podłożu seksualnym lub } \\
\text { odnoszące się do płci }\end{array}$ & $\begin{array}{l}15,6-51,7 \% \text { (kobiety) } \\
2,3-7,6 \% \text { (mężczyźni) }\end{array}$ & $\begin{array}{l}\text { Polska/ } \\
4284 \text { (osoby } \\
\text { studiujące) }\end{array}$ \\
\hline
\end{tabular}

Uzupełnienie: W tabeli podano albo konkretną liczbę, albo zakres liczbowy w zależności od sposobu definiowania, formy oraz miejsca występowania zjawiska.

Źródło: opracowanie własne na podstawie: CBOS (2007); Grabowska, Rawłuszko (2016): 11-76; CBOS (2017); CBOS (2018); RPO (2018).

11 Szwiec (2006): 26-27. 
Ponadto należy zauważyć, że zagadnienia molestowania seksualnego wiążą się często z traumatycznymi przeżyciami, o których trudno jest - zarówno kobiecie, jak i mężczyźnie - mówić z osobą przeprowadzającą ankietę. Ma to wpływ na chęć (lub bardziej niechęć) podzielenia się z obcą osobą swoim doświadczeniem. Dotyczy to nie tylko kobiet. Anna Góralewska-Słońska zauważa, że zgodnie z wynikami badań mężczyźni częściej byli niechętni do ujawniania intymnych informacji na temat agresji seksualnej w pracy ${ }^{12}$.

\section{KONSEKWENCJE I DETERMINANTY ZGEASZANIA MOLESTOWANIA}

O ile dostępne sa liczne badania na temat zakresu molestowania seksualnego w Polsce, o tyle znacznie trudniej jest o wyniki badań dotyczace jego wpływu na rynek pracy i gospodarkę. W dalszej części przedstawione zostana rezultaty badań na temat molestowania seksualnego $\mathrm{w}$ perspektywie ekonomicznej z Chin i USA.

W 2009 r. w Chinach przeprowadzono badania ankietowe na próbie składającej się z 1837 osób (63\% kobiet i 37\% mężczyzn) z 10 przedsiębiorstw z prowincji Beijing, Guangdong, Jiangsu i Hebei (por. wykres 1). W grupie tej 19,8\% osób przyznało, że były ofiarami molestowania seksualnego, natomiast następne $23,9 \%$ badanych, że albo słyszało, albo było świadkami molestowania seksualnego ich koleżanek lub kolegów w pracy. Co ważne, ankietowani wskazywali na konsekwencje mikroekonomiczne molestowania dla jakości i efektywności ich pracy zawodowej. Skutkiem wskazywanym przez większość badanych była niższa wydajność w pracy. Osoby, które doświadczyły tego rodzaju dyskryminacji ekonomicznej, przyznawały, że ich doświadczenia prowadziły do popełniania większej liczby błędów w miejscu zatrudnienia, ale także do niechęci wobec chodzenia do pracy oraz do częstszego uchylania się od niej. Część osób przyznała, że molestowanie seksualne stało się powodem znalezienia nowego miejsca zatrudnienia ${ }^{13}$.

Z kolei analizy przeprowadzone na danych pochodzacych z lat 2003 i 2004 z przedsiębiorstw USA ${ }^{14}$, które można zaklasyfikować jako należące do perspektywy mezoekonomicznej, dotyczyły częstotliwości zgłaszania molestowania seksualnego w miejscu pracy w zależności od takich cech, jak: płeć, zmaskulinizowanie lub sfeminizowanie sekcji gospodarki oraz stanowisko pracy. Wśród kobiet kadry menedżerskiej wyraźnie częściej niż w grupie pracujacych jako podwładni zgłaszano przypadki molestowania seksualnego. Wydaje się, że więcej przypadków molestowania seksualnego zgłasza-

\footnotetext{
12 Góralewska-Słońska (2013): 300.

13 Portal China.org.cn (2011).

14 McLaughlin, Uggen, Blackstone (2012): 625-647.
} 
nych przez osoby na kierowniczych stanowiskach może być efektem większej wrażliwości lub świadomości prawnej tej grupy. Jednak hipotezę tę autorzy odrzucili, między innymi ze względu na zbyt duże (istotne statystycznie) różnice pomiędzy liczbą przypadków molestowania zgłaszanych przez kobiety i mężczyzn (na niekorzyść kobiet).

\section{Wykres 1}

Wpływ molestowania seksualnego na wyniki pracy zawodowej

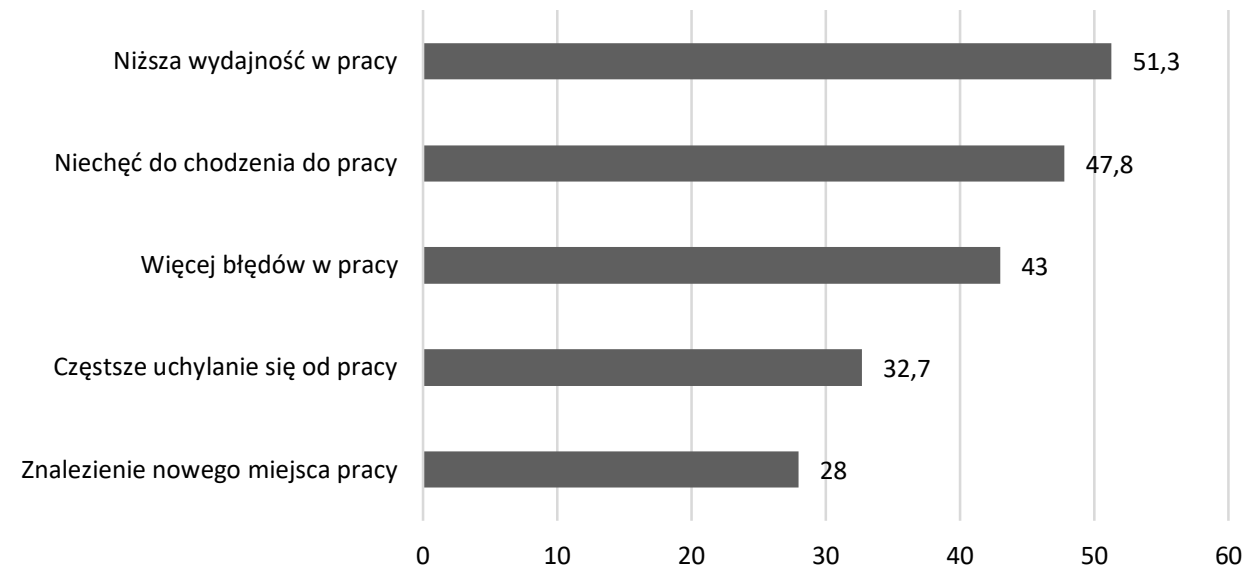

Źródło: Portal China.org.cn (2011).

\section{Wykres 2}

Odsetek osób zgłaszających molestowanie ze względu na płeć, zmaskulinizowanie lub sfeminizowanie sekcji gospodarki oraz grupę zawodową

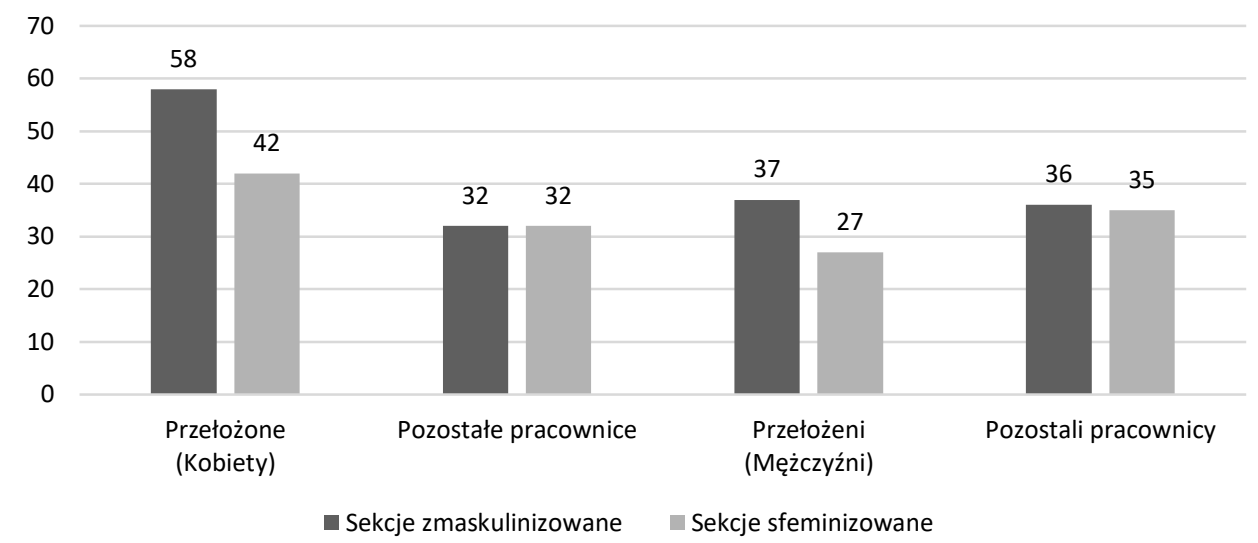

Źródło: McLaughlin, Uggen, Blackstone (2012): 625-647. 
Kolejną cechą różnicującą prawdopodobieństwo wystapienia molestowania seksualnego był stopień zmaskulinizowania lub sfeminizowania sektora gospodarki (por. wykres 2). Kobiety pracujace w sektorach zmaskulinizowanych zgłaszały zdecydowanie częściej występowanie badanego zjawiska niż $\mathrm{w}$ sektorach sfeminizowanych. Badania jakościowe przeprowadzone w tym zakresie wskazały, że kobiety, które pracowały w branżach zdominowanych przez mężczyzn, reprezentowały postawy tolerancji wobec molestowania. Respondentki zgłaszały poczucie wyizolowania, a także molestowania seksualnego ze strony współpracowników oraz przełożonych, sprowadzającego je na „ich właściwe miejsce”. W przypadku podjęcia próby wyłamania się poza społeczne oczekiwania - zarówno przez kobiety, jak i przez mężczyzn zdarzały się odpowiedzi w postaci gróźb. Pomimo występowania molestowania seksualnego $\mathrm{w}$ przedsiębiorstwach zaliczających się do zmaskulinizowanych sektorów gospodarki ankietowane kobiety reprezentowały postawę tolerowania tych zachowań ze względu na chęć utrzymania swoich stanowisk pracy ${ }^{15}$.

\section{POMIAR FINANSOWYCH KOSZTÓW MOLESTOWANIA SEKSUALNEGO}

Najszerzej metody kalkulacji kosztów molestowania seksualnego przedstawili Sabir I. Giga, Helge Hoel i Duncan Lewis ${ }^{16}$. Dokonali oni estymacji kosztów pieniężnych molestowania seksualnego w Wielkiej Brytanii na poziomie mikro-, mezo- i makroekonomicznym. Oceniając koszty na poziomie jednostki, stwierdzili, że sa one zależne od indywidualnych przypadków i wykazują znaczne zróżnicowanie przy uwzględnieniu upływu czasu, rodzaju sektora oraz organizacji. Jeżeli chodzi o wycenę kosztów organizacyjnych i społecznych na poziomie mezoekonomicznym, autorzy badania ${ }^{17}$ przedstawili dwa podejścia:

- indukcyjne - zakładające sumowanie poszczególnych elementów składowych według dokonywanych kalkulacji i ocen;

- dedukcyjne - w którym wyszli od oszacowania zachorowalności i wypadków przy pracy, które z kolei mogą być postrzegane jako bardziej wiarygodne ze względu na bardziej rzeczywisty i systematyczny charakter, oraz faktu dostępności konkretnych danych na ten temat dla Wielkiej Brytanii.

W pierwszej kolejności zostana przedstawione dwa etapy dokonywania oceny wpływu występowania zjawiska molestowania seksualnego na przedsiębiorstwa według ostatniego podejścia, a więc dedukcyjnego. Zatem aby określić koszt molestowania w miejscu pracy, Giga, Hoel i Lewis ${ }^{18}$ wzięli

\footnotetext{
15 McLaughlin, Uggen, Blackstone (2012): 625-647.

16 Giga, Hoel, Lewis (2008)

17 Giga, Hoel, Lewis (2008): 24.

18 Giga, Hoel, Lewis (2008): 11.
} 
pod uwagę koszty stresu związanego z praca, oszacowane wcześniej przez Johannę Beswick, Joanne Gore i Davida Palfermana ${ }^{19}$ dla lat 1995-1996. Beswick i jej współpracownicy określili, że stres w pracy wpływa na co najmniej 0,5 mln pracowników na brytyjskim rynku pracy, którzy w efekcie przeciętnie przez 29 dni korzystają z dni wolnych (ogółem: ponad 13 mln dni rocznie). W konsekwencji przyjęli, że stres spowodowany praca kosztował społeczeństwo między 3,7 a 3,8 mld GBP rocznie (przy uwzględnieniu cen z lat 1995/96), natomiast udział kosztów ponoszonych z tytułu molestowania ocenili na od 10\% do $20 \%$ wcześniej podanej wartości (średnio: $15 \%$ ) $^{20}$. Wykorzystując te szacunki, Giga, Hoel i Lewis przyjęli, z kolei, że relacje kosztów stresu i molestowania pozostają stałe. Uwzględnili również inflację na poziomie 2\% rocznie. Przy takich założeniach według ich obliczeń szacunkowy koszt stresu wywołanego pracą za rok 2007 wyniósł 4,55 mld GBP. Kwotę tę pomnożyli przez 15\% i w efekcie otrzymali wynik $682 \mathrm{mln}$ GBP rocznie, który jest przybliżoną wartością kosztów ponoszonych przez społeczeństwo Wielkiej Brytanii w związku z molestowaniem ${ }^{21}$.

Drugim etapem w podejściu dedukcyjnym była próba wyceny - na podstawie danych Office for National Statistics (ONS) - kosztów absencji będących wynikiem molestowania. Giga wraz ze współpracownikami - na podstawie iloczynu: mediany dziennego wynagrodzenia osób pełnozatrudnionych (91,40 GBP), liczby pracowników, którzy byli nieobecni w pracy z powodu stresu (500 000), oraz liczby dni wspomnianych nieobecności (29) - obliczyli, że ogólne koszty absencji w miejscu pracy z powodu stresu wyniosły w Wielkiej Brytanii w roku 2007 w przybliżeniu 1,325 mld GBP. Przyjmując wcześniejszy udział kosztów molestowania (15\%), otrzymali wartość 199 mld GBP rocznie. Autorzy przytaczają również dla porównania wyniki opublikowane przez Konfederację Przemysłu Brytyjskiego. Przedstawiciele tej ostatniej instytucji ocenili, że koszty absencji z powodu molestowania to około $534 \mathrm{mln}$ GBP. Należy podkreślić, że wartość ta nie bierze pod uwagę takich kosztów, jak: wpływ molestowania na osoby współpracujące, zastępstw czy utraty produktywności ${ }^{22}$.

Jeżeli chodzi o podejście indukcyjne, wykorzystuje ono kalkulacje dotyczące wielu sfer, więc jest bardziej złożone. Szacunek kosztów molestowania dla organizacji oparto na kosztach związanych z absencja, rotacja personelu oraz zmianami w poziomie produktywności.

Aby wyliczyć koszty związane z absencja, w pierwszej kolejności dokonano kalkulacji liczby absencji w miejscu zatrudnienia z powodu doświadczenia przez osoby pracujące molestowania w miejscu pracy $\left(\mathrm{N}_{\text {mol }}\right)$. Wartość ta została określona w dniach i osiagnęła 33495000 dni w 2007 r. Liczbę tę otrzymano przy wykorzystaniu następującej formuły:

\footnotetext{
19 Beswick, Gore, Palferman (2006).

20 Beswick, Gore, Palferman (2006): 1.

${ }^{21}$ Giga, Hoel, Lewis (2008): 25.

${ }^{22}$ Giga, Hoel, Lewis (2008): 26.
} 


$$
\mathrm{N}_{\text {mol }}=\mathrm{P} \times \mathrm{m} \times 7 \mathrm{dni}
$$

gdzie: P - liczba osób pracujących ogółem w gospodarce; m - udział osób pracujących, które doświadczyły molestowania w pracy (wartość szacunkowa), w wyniku czego były nieobecne w pracy przez co najmniej 7 dni.

Na podstawie tych danych wyliczono koszty nieobecności w pracy, wynikających z molestowania (KNMS) na poziomie 3,06 mld GBP. Wartość tę otrzymano zgodnie ze wzorem:

$$
\mathrm{KNMS}=\mathrm{W}_{\text {dzien }} \times \mathrm{N}_{\text {mol, }}
$$

gdzie: $\mathrm{W}_{\text {dzien }}$ - przeciętne dzienne wynagrodzenie.

Następnym krokiem było oszacowanie kosztów rotacji personelu. Ewaluację rozpoczęto od wyliczenia liczby pracujących, którzy opuścili organizację w konsekwencji doświadczenia molestowania $\left(\mathrm{P}_{\text {rezygn }}\right)$. Otrzymano liczbę 199375 osób na podstawie formuły:

$$
\mathrm{P}_{\text {rezygn }}=\mathrm{P} \times \mathrm{cz} \times \mathrm{f},
$$

gdzie: cz - częstość występowania rezygnacji z pracy z powodu molestowania, $\mathrm{f}$ - fluktuacja kadr (w \%). Dalej otrzymano wartość kosztów rotacji personelu na skutek doświadczenia molestowania seksualnego (KR). Wartość tę określono na poziomie 1,55 mld GBP, według wzoru:

$$
\mathrm{KR}=\mathrm{P}_{\text {rezygn }} \times \mathrm{KZ}
$$

gdzie: KZ - przeciętny koszt znalezienia zastępstwa.

W kolejnym etapie badano koszty powodowane utratą produktywności (KUP). Trudnością było tu oszacowanie, jaki jest spadek produktywności wywołany występowaniem zjawiska molestowania w pracy. Za Helge Hoelem i Carym L. Cooperem ${ }^{23}$ przyjęto, że analizowany spadek produktywności sięga około 1,5\%-2\% potencjalnej produktywności w gospodarce. Podjęto się więc oceny liczby dni utraconej produktywności z powodu molestowania (D ${ }_{\text {UPM }}$ ). W tym celu wykorzystano wzór:

$$
\mathrm{D}_{\mathrm{UPM}}=\mathrm{P} \times \mathrm{TR} \times \mathrm{DR} \times \mathrm{u},
$$

gdzie: TR - liczba tygodni roboczych w roku, DR - liczba dni roboczych w tygodniu (5), u - spadek produktywności (w \%). Otrzymaną liczbę $100 \mathrm{mln}$ dni wykorzystano do obliczenia całkowitego kosztu utraty produktywności z powodu molestowania ( $\mathrm{KUP}_{\text {mol }}$ ) z uwzględnieniem formuły:

$$
\mathrm{KUP}_{\mathrm{mol}}=\mathrm{P} \times \mathrm{W}_{\text {tyg }} \times \mathrm{TR} \times \mathrm{u}
$$

${ }^{23}$ Hoel, Cooper (2000). 
gdzie: $\mathrm{W}_{\text {tyg }}$ - przeciętne wynagrodzenie tygodniowe. W ten sposób otrzymano wartość 9,14 mld GBP ${ }^{24}$.

Po zsumowaniu otrzymanych liczb, będących wyceną wartości kosztów molestowania seksualnego z powodu absencji, fluktuacji personelu oraz utraty produktywności, otrzymano kwotę $13,75 \mathrm{mln} \mathrm{GBP}^{25}$. Wartość ta stanowi szacunkowy koszt molestowania seksualnego w Wielkiej Brytanii w 2007 r.

Warto zaprezentować jeszcze szacunki na poziomie makroekonomicznym, a więc dotyczące całości gospodarki, przeprowadzone z wykorzystaniem podejścia Fiammetty Gordon i Davida Risleya ${ }^{26}$, zgodnie z którym koszt społeczny molestowania w regionie sięga $1,4 \%-2 \%$ PKB, a także przyjmując wartość PKB dla 2004 r. dla Wielkiej Brytanii (1176,5 mld GBP). Uwzględniając powyższe, Giga, Hoel i Lewis stwierdzili, że obniżka o 1,5\% w całkowitej produktywności Wielkiej Brytanii w 2007 r. spowodowałaby koszt finansowy na poziomie około 17,65 mld GBP w skali rocznej ${ }^{27}$.

Podsumowując zaprezentowane przez Gigę, Hoela i Lewisa wyniki, otrzymujemy szacunkowe koszty molestowania seksualnego mieszczące się $\mathrm{w}$ przedziale od $682 \mathrm{mln}$ do 17,65 mld GBP w skali rocznej. Warto zwrócić uwagę na to, że ta ostatnia kwota jest ponad 25-krotnie wyższa od pierwszej ${ }^{28}$. Podobnie jak w przypadku zakresu występowania zjawiska molestowania seksualnego, próby oceny wpływu badanego zjawiska na gospodarkę mają szeroki margines błędu, nieodłącznie związany z metodami szacunkowymi.

W literaturze można znaleźć inne jeszcze szacunki kosztów molestowania seksualnego. I tak Heinz Leymann ${ }^{29}$ - biorąc pod uwagę długie okresy zwolnień lekarskich osoby molestowanej, związany z tym spadek poziomu produkcji, konieczność częstych interwencji ze strony osób pracujących w kadrach, doradców personelu, zarządzających na różnych szczeblach organizacji, usługi medycyny pracy, zewnętrznych konsultantów - wycenia ekonomiczne konsekwencje dla organizacji i społeczeństwa na kwoty od 30000 do 100000 USD rocznie $\mathrm{w}$ przeliczeniu na jedną osobę doświadczającą molestowania ${ }^{30}$. Leymann w swojej publikacji odnosi się do Szwecji, jego badania jednak obejmowały również inne kraje, takie, jak USA, Wielka Brytania, Australia, Kanada, Niemcy czy Norwegia.

Z kolei Ronnie Sandroff ${ }^{31}$ w 1988 r. przeprowadziła badanie ankietowe wśród 160 kobiet zatrudnionych w przedsiębiorstwach z listy „Fortune 500”. Celem była ewaluacja kosztu molestowania seksualnego kobiet w miejscu pracy. Koszty związane z absencja, rotacją personelu oraz utratą produktywności zostały dodane i ekstrapolowane do hipotetycznego przedsiębiorstwa, w którym

${ }^{24}$ EU-OSHA (2014): 13; Giga, Hoel, Lewis (2008): 28.

25 Giga, Hoel, Lewis (2008): 30.

${ }^{26}$ Georgiou, Thomson, Richardson-Owen, Edwards (2009): 1035-1046, za: Gordon, Risley (1999).

27 EU-OSHA (2014): 14; Giga, Hoel, Lewis (2008): 30.

28 EU-OSHA (2014): 14.

29 Leymann (1990): 119-126.

30 Leymann (1990): 123.

31 Sandroff (1988). 
zatrudnionych miałoby być więcej niż 20000 osób. Dla firmy tych rozmiarów Sandroff obliczyła, że koszt molestowania seksualnego byłby na poziomie 6,7 mln USD rocznie ${ }^{32}$. Juliet Hassard z zespołem dokonali przeliczenia tej wartości do stanu na 1 marca 2013 r. Według ich kalkulacji w tym czasie koszt ten wzrósł do 13,68 mln USD (10,67 mln EUR $)^{33}$.

\section{Wykres 3}

Koszty molestowania seksualnego dla państwa w latach 1992-1994 w USA (mln USD)

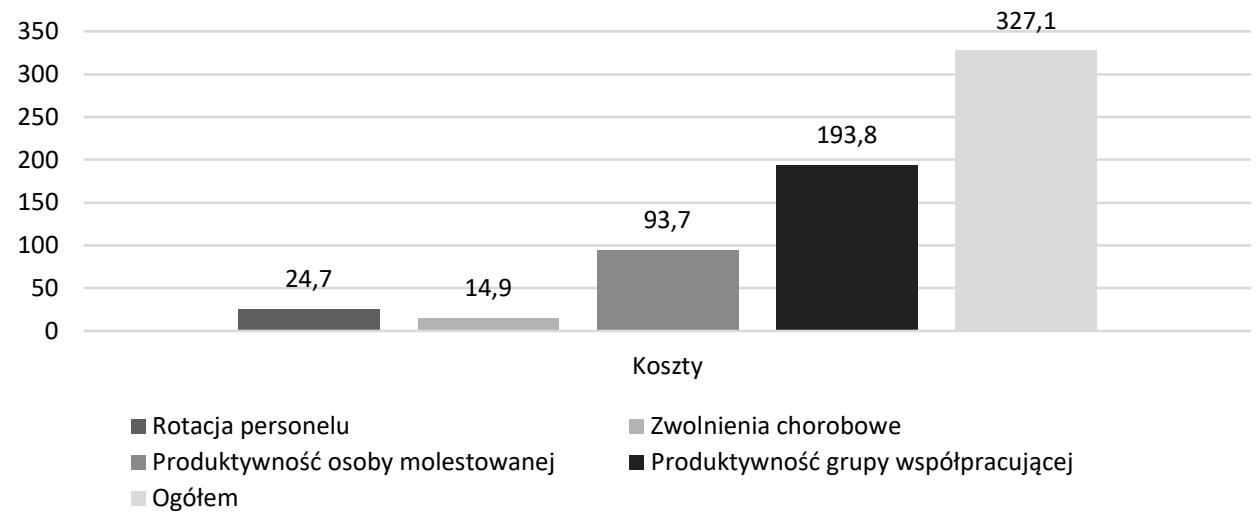

Źródło: Hersch (2015): 1-10.

Hersch $^{34}$ natomiast przedstawia koszty molestowania seksualnego, jakie poniosły USA jako państwo w latach 1992-1994 (por. wykres 3). Na ogólna kwotę 327 mln USD złożyły się koszty ponoszone z tytułu rotacji personelu, zwolnień chorobowych, produktywności osoby molestowanej oraz grupy z nia współpracującej.

Dokonując swego rodzaju podsumowania szacunków kosztów molestowania seksualnego, należy zwrócić uwagę na trudności w dokonywaniu porównań pomiędzy krajami. Pierwszą są zróżnicowane rozmiary gospodarek, w których dokonano obliczen ${ }^{35}$. Kolejną barierą są różnice w zastosowanych metodach, jak i w poziomach analiz i przedstawianych kalkulacji. Jednak biorąc pod uwage nawet najniższe wartości wyceny skali wpływu molestowania seksualnego w miejscu pracy na gospodarkę, należy podkreślić, że są to wyniki znacząco wysokie i implikujące konieczność ograniczania tego rodzaju kosztów.

32 EU-OSHA (2014): 12, za: Sandroff (1988): 69-73.

33 EU-OSHA (2014): 37.

${ }^{34}$ Za: US Merit Systems Protection Board, Office of Policy and Evaluation (1995). Sexual Harassment in the Federal Workplace: Trends, Progress, and Continuing Challenges. Washington, DC: US Government Printing Office.

35 EU-OSHA (2014): 27. 


\section{KOSZTY MOLESTOWANIA SEKSUALNEGO DLA POLSKI}

W dalszej części podjęta zostanie próba oszacowania kosztów molestowania seksualnego dla Polski. W tym celu omówione zostaną podstawowe założenia, metody obliczeniowe oraz kalkulacje.

Przy użyciu metody indukcyjnej można dokonać próby oszacowania kosztu finansowego dla organizacji, jakie niesie ze sobą zjawisko molestowania. Dostosowując wykorzystaną przez Gigę, Hoela oraz Lewisa metodę obliczeń do danych statystycznych dostępnych dla Polski, można w przybliżeniu obliczyć koszty związane $\mathrm{z}$ absencją $\mathrm{w}$ pracy oraz utrata produktywności na poziomie przedsiębiorstw.

Aby skalkulować koszty absencji w pracy z powodu molestowania, należy wziąć pod uwagę przeciętne miesięczne wynagrodzenie brutto w gospodarce narodowej, które za rok 2018 wyniosło $4585,03 \mathrm{PLN}^{36}$. Jeżeli pomnożymy tę wartość przez 12 miesięcy, wówczas otrzymamy przeciętne roczne wynagrodzenie brutto na poziomie 55 020,36 PLN ( $\mathrm{W}_{\text {roczne }}$ ). W kalendarzu w $2018 \mathrm{r}$. było 250 dni roboczych $\left(\mathrm{D}_{\mathrm{rob}}\right)^{37}$. Zatem możemy już obliczyć przeciętne wynagrodzenie dzienne brutto ( $\mathrm{W}_{\text {dzien }}$ ), które będzie potrzebne $\mathrm{w}$ dalszych wyliczeniach:

$$
\mathrm{W}_{\text {dzien }}=\mathrm{W}_{\text {roczne }}: \mathrm{D}_{\text {rob }}=220,08 \text { PLN. }
$$

W literaturze wśród istotnych skutków molestowania seksualnego wskazuje się objawy psychosomatyczne i psychiatryczne u osób molestowanych. Zaburzenia lękowe, obniżenia nastroju, depresje, załamania nerwowe, myśli i próby samobójcze to tylko niektóre zaburzenia psychiczne i zaburzenia zachowania, które pojawiaja się u ofiar badanego tu zjawiska. Z danych opublikowanych przez Zakład Ubezpieczeń Społecznych (ZUS) można wywnioskować, że liczba dni absencji chorobowych z tytułu zaburzeń psychicznych i zaburzeń zachowania (sytuacje choroby własnej osoby ubezpieczonej w ZUS) w 2018 r. wyniosła 19 424,9 tys. $\left(\mathrm{N}_{\text {absencij ogótem }}\right)^{38}$. Przyjmując założenie, że około $13 \%$ absencji osób pracujaccych było konsekwencją doświadczenia molestowania w miejscu pracy $\left(u_{\text {mol }}\right)^{39}$, otrzymujemy liczbę dni absencji na poziomie 2525237 dni, zgodnie z formuła:

$$
\mathrm{N}_{\text {mol }}=\mathrm{N}_{\text {absencji ogóom }} \times \mathrm{u}_{\text {mol }}=19424,9 \text { tys. dni } \times 13 \%=2525237 \text { dni. }
$$

${ }^{36}$ GUS (2020a).

${ }^{37}$ Portal KalendarzSwiąt.pl 2009-2020.

${ }^{38}$ ZUS (2019a): 42.

${ }^{39}$ Zgodnie z danymi przedstawianymi przez Health and Safety Executive w raporcie dotyczącym sytuacji w Wielkiej Brytanii nt. problemów zdrowotnych wynikających z pracy zawodowej, w latach 2009/2010 i 2011/2012 odsetek osób wskazujących na molestowanie jako główne źródło problemu wynosił przeciętnie 13\%. Por. HSE (2019): 2. Przyjęto tu zatem niższą wartość niż przez Beswick, Gore, Palfermana (2006). 
Obliczając przybliżone koszty nieobecności wynikających z doświadczenia przez osoby pracujące molestowania w miejscu pracy (KNMS) w 2018 r., należy uwzględnić zatem:

$$
\mathrm{KNMS}=\mathrm{W}_{\text {dzien }} \times \mathrm{N}_{\text {mol }}=220,08 \mathrm{PLN} \times 2525237 \mathrm{dni}=555754158,9 \mathrm{PLN} .
$$

Następnym etapem jest szacowanie wartości luki produktu krajowego brutto (PKB), a więc części potencjalnego produktu krajowego, którą utracono z powodu spadku poziomu produktywności, wynikającego z doświadczenia przez osoby pracujące molestowania seksualnego w miejscu pracy (KUP ${ }_{\text {mol }}$ ). Przyjmując - za Hoelem i Cooperem ${ }^{40}$ - że spadek produktywności w ujęciu procentowym sięga około $1,5 \%-2 \%$ potencjalnej produktywności, a także biorąc pod uwagę na podstawie BAEL z 2018 r. przeciętną liczbę pracujących w gospodarce narodowej - 16484 tys. osób ${ }^{41}(\mathrm{P})$, możemy wykorzystać następujący wzór:

$$
\begin{gathered}
\mathrm{KUP}_{\text {mol }}=\mathrm{P} \times \mathrm{D}_{\text {rob }} \times \mathrm{W}_{\text {dzien }} \times \mathrm{u}=16484 \text { tys. } \times 250 \times 202,08 \times 1,5 \%= \\
=13604245,2 \text { tys. PLN } .
\end{gathered}
$$

Niestety w polskich danych statystycznych nie ma dostępnych informacji na temat kosztów rotacji personelu wynikających z doświadczenia molestowania seksualnego, więc możemy oszacować jedynie część kosztów - będacych konsekwencja absencji w pracy oraz utraty produktywności na poziomie przedsiębiorstw w wyniku molestowania seksualnego. Reasumując, otrzymujemy, że w Polsce w 2018 r. koszty związane z:

- absencja w pracy wyniosły: 555754158,9 PLN $=555754,159$ tys. PLN,

- ze spadkiem produktywności: 13604245,2 tys. PLN, a zatem po zsumowaniu

- koszty ogółem stanowiły: 14159 999, 36 tys. PLN.

Przyjęto też szersze ujęcie, w którym wzięto także pod uwagę wszelkie koszty makroekonomiczne ponoszone na rynku pracy, przez budżet państwa, a także na poziomie całej gospodarki. I tak Gordon i Risley ${ }^{42}$ oszacowali, że koszt społeczny molestowania w regionie sięga 1,4\%-2\% PKB. Jeżeli weźmiemy pod uwagę wartość PKB dla Polski za 2018 r. na poziomie 2115242 mln PLN ${ }^{43}$, to możemy oceniać, że redukcja produktywności na poziomie 1,5\% PKB w 2018 r. mogła spowodować koszt finansowy na poziomie 31 728,6 mln PLN ${ }^{44}$. Biorąc pod uwagę przedział od 1,4\% do 2,0\% PKB, otrzymamy przedział kwotowy od 29 613,4 do 42 304,8 mln PLN w skali rocznej.

\footnotetext{
${ }^{40}$ Hoel, Cooper (2000).

${ }^{41}$ GUS (2019): 25.

${ }^{42}$ Hoel, Sparks, Cooper (2001): 50, za: Gordon, Risley (1999).

${ }^{43}$ GUS (2020b): 691.

44 Por. Giga, Hoel, Lewis (2008): 30.
} 
Przechodząc do analizy kosztów molestowania według podejścia dedukcyjnego na poziomie makroekonomicznym, należy wskazać na koszty ponoszone przez państwo, wśród których warto wymienić szacunkową wartość wydatków na świadczenia z ZUS poniesionych w $2018 \mathrm{r}$. z powodu konieczności przejścia przez ofiary molestowania na zwolnienie lekarskie. ZUS przedstawia ranking jednostek chorobowych powodujących niezdolność do pracy, generujących najwyższe wydatki na świadczenia związane z tą niezdolnością. W zestawieniu tym można wyróżnić takie, które były spowodowane:

- reakcją na ciężki stres i zaburzenia adaptacyjne (udział w wydatkach ogółem na poziomie $2 \%$ ),

- epizodami depresyjnymi (odpowiednio: $1,2 \%$ ),

- innymi zaburzeniami lękowymi $(1,1 \%)$,

- zaburzeniami depresyjnymi nawracającymi $(1,1 \%)^{45}$.

Podsumowując, otrzymujemy łączny udział o wartości 5,4\% w wydatkach ogółem na świadczenia związane z niezdolnością do pracy, tj. 5,4\% z 36812 309,3 tys. PLN, co daje nam kwotę 1987 864,7 tys. PLN. Jeżeli ponownie przyjąć założenie o tym, że świadczenia ZUS w związku z niezdolnością do pracy w konsekwencji wystapienia molestowania seksualnego stanowią około 15\% $(10 \%-20 \%)^{46}$ wydatków wynikających z chorób psychicznych, wówczas otrzymamy 298 179,7 tys. PLN. Jest to jedynie kwota uwzględniajacca wydatki ZUS na świadczenia związane ze zwolnieniami lekarskimi ofiar molestowania seksualnego w przedsiębiorstwach, a więc nie dotyczy całości wyceny ${ }^{47}$.

Konkludując przedstawione tu wcześniej kalkulacje i szacunki o najszerszym zakresie, można zauważyć, że zakres kosztów finansowych zależy od poziomu analizy oraz przyjętych założeń. Koszt ten waha się pomiędzy około 14,2 a około 31,7 mld PLN. Ostatnia kwota jest ponad dwukrotnie większa niż pierwsza, co jest związane z różnicami w zastosowanych metodach kalkulacji i szacowania.

\section{ZAKOŃCZENIE}

Celem głównym artykułu była próba rozważenia molestowania seksualnego jako złożonego i interdyscyplinarnego zjawiska występującego na rynku pracy w sferze pracy i płacy w ujęciu ekonomicznym. Rozważania przeprowadzono w ujęciu teoretycznym, a następnie empirycznym.

W części teoretycznej stwierdzono, że molestowanie seksualne jest nieakceptowalnym zachowaniem, które może mieć charakter fizyczny, werbalny lub niewerbalny. Może przejawiać się w formie szantażu seksualnego oraz tworzenia wrogiego środowiska - ze względu na płeć lub z podtekstem erotycznym. Każda z tych form może jednocześnie przyczyniać się do powstawania innych form dyskryminacji w sferze pracy i płacy.

${ }^{45}$ ZUS (2019b): 34.

${ }^{46}$ Za: Beswick, Gore, Palferman (2006).

${ }^{47} \mathrm{Z}$ tego powodu kwota ta będzie pominięta w dalszych podsumowaniach. 
W części empirycznej skonkludowano, że zakres molestowania seksualnego w Polsce w zależności od ośrodka badawczego szacuje się w granicach od $2 \%$ do 88\%. Tak duże zróżnicowanie odpowiedzi ma wiele przyczyn: metodologia, sposób przeprowadzania badania, różny stopień percepcji, szczerości i świadomości u osób ankietowanych. Na podstawie wyników badań z Chin i USA dowiedziono, że molestowanie seksualne niesie ze sobą negatywne konsekwencje w pracy zawodowej, a jest determinowane różnymi czynnikami, takimi jak: płeć, zmaskulinizowanie lub sfeminizowanie sekcji gospodarki oraz stanowisko pracy.

W celu zweryfikowania przyjętej we wprowadzeniu hipotezy badawczej o tym, że molestowanie seksualne $\mathrm{w}$ miejscu pracy przyczynia się do powstawania mierzalnych kosztów o charakterze finansowym, których ograniczenie mogłoby realnie przyczynić się do osiagania wyższego poziomu PKB, następnie rozpatrywano metody pomiaru kosztów finansowych molestowania seksualnego na podstawie szacunków dotyczących Wielkiej Brytanii, Szwecji oraz USA. Wyniki - ze względu na wielkość państwa, metodologię badania, poziom przeprowadzanych analiz - były mocno zróżnicowane, jednak koszt finansowy molestowania seksualnego sięgał nawet $2 \%$ PKB w przypadku Wielkiej Brytanii. Następnie podjęto próbę obliczenia kosztu molestowania seksualnego dla społeczeństwa i gospodarki polskiej dla 2018 r. Wykorzystano do tego celu omówione wcześniej metody: indukcyjną oraz dedukcyjną. Uwzględniono zwłaszcza koszty związane z nieobecnościami w pracy oraz z luką PKB spowodowaną obniżoną produktywnością ofiar molestowania seksualnego w miejscu pracy. Otrzymano wartość zawierająca się w przedziale od około 14,2 do około 31,7 mld PLN. Znaczne różnice pomiędzy wynikami wynikają z wykorzystania metod szacunkowych.

Biorąc pod uwagę wysoki - nawet jeżeli uwzględnić tę niższą wartość - oszacowany koszt występowania molestowania seksualnego w Polsce, warto zarekomendować zwrócenie zdecydowanie większej niż do tej pory uwagi ustawodawcy i przedsiębiorstw na ograniczanie analizowanego zjawiska w sferze pracy i płacy. Potencjalną korzyścią społeczno-ekonomiczna jest obniżenie nakładów finansowych ponoszonych w organizacjach i gospodarce. Co więcej, istotne jest prowadzenie dalszych badań w kierunku wytyczenia potencjalnych działań na rzecz ograniczania molestowania seksualnego w miejscu pracy. Rozszerzenie wprowadzonych jeszcze przed akcesją Polski do Unii Europejskiej w życie przepisów do Kodeksu pracy, a dotyczących molestowania seksualnego, może bowiem przynieść realne korzyści dla przedsiębiorstw i gospodarki.

\author{
Baha Kalinowska-Sufinowicz \\ Uniwersytet Ekonomiczny w Poznaniu \\ baha.kalinowska-sufinowicz@ue.poznan.pl \\ https://orcid.org/0000-0001-5651-5159
}

Beswick, J., Gore, J., Palferman, D. (2006). Bullying at Work: A Review of the Literature. Buxton: $1-59$.

CBOS (2007). Molestowanie seksualne. Warszawa.

CBOS (2017). Molestowanie czy komplement. Warszawa.

CBOS (2018). Molestowanie seksualne. Warszawa. 
EU-OSHA (2014). Obliczanie kosztów związanych ze stresem w pracy i innymi zagrożeniami psychospołecznymi. Luksemburg.

Fitzgerald, L.F., Gelfand, M.J., Fritz, D. (1995). Measuring sexual harassment: theoretical and psychometric advances. Basic and Applied Social Psychology 17(4): 425-445.

Georgiou, S., Thomson, M., Richardson-Owen, A., Edwards, H. (2009). The costs of workplace injuries and work-related ill health in the UK. Ege Academic Review 9(3): 1035-1046.

Giga, S.I., Hoel, H., Lewis, D. (2008). The Costs of Workplace Bullying. Bradford.

Góralewska-Słońska, A. (2013). Od romansu do molestowania seksualnego w środowisku pracy. Acta Universitatis Lodziensis. Folia Oeconomica 288: 295-304.

Grabowska, M., Rawłuszko, M. (2016). Powszechność i trwałość przemocy seksualnej wobec kobiet: wyzwania metodologiczne i wyniki badań ankietowych, [w:] M. Grabowska, A. Grzybek, (red.), Przełamać tabu. Raport o przemocy seksualnej. Warszawa: 11-76.

GUS (2019). Aktywność ekonomiczna ludności - IV kwartał 2018 r. Warszawa.

GUS (2020a). Przeciętne miesięczne wynagrodzenia w gospodarce narodowej w latach 19502018. <https://stat.gov.pl/obszary-tematyczne/rynek-pracy/pracujacy-zatrudnieni-wynagrodzenia-koszty-pracy/przecietne-miesieczne-wynagrodzenie-w-gospodarce-narodowej-w-latach-1950-2018,2,1.html> [dostęp: 29.01.2020].

GUS (2020b). Rocznik Statystyczny Rzeczypospolitej Polskiej. Warszawa.

Hoel, H., Cooper, C.L. (2000). Destructive Conflict and Bullying at Work. Manchester School of Management. Manchester: University of Manchester, Institute of Science and Technology.

Hoel, H., Sparks, K., Cooper, C.L. (2001). The Cost of Violence/Stress at Work and the Benefits of a Violence/Stress-free Working Environment. Geneva.

Hołyst, B. (2004). Patologia w miejscu pracy: mobbing i molestowanie seksualne. Prokuratura i Prawo 1: 7-30.

HSE (2019). Work-related Stress, Anxiety or Depression Statistics in Great Britain. Bootle.

Kalinowska-Nawrotek, B. (2004). Formy dyskryminacji kobiet na polskim rynku pracy. Ruch Prawniczy, Ekonomiczny i Socjologiczny 66(2): 231-245.

Kalinowska-Sufinowicz, B. (2013). Polityka społeczno-gospodarcza państwa wobec pracy kobiet. Poznań.

Kalinowska-Sufinowicz, B. (2020). Jak reagować na molestowanie seksualne? Poradnik. Wersja 2.0. Poznań.

Kędziora, K. (2008). Molestowanie i molestowanie seksualne w zatrudnieniu, [w:] A. Czerwińska (red.), Niemoralne propozycje. Molestowanie seksualne w miejscu pracy. Warszawa: 14-21

Hersch, J. (2015). Sexual harassment in the workplace. IZA World of Labor 188: 1-10.

Leymann, H. (1990). Mobbing and psychological terror at workplaces. Violence and Victims 5(2): $119-126$.

McLaughlin, H., Uggen, C., Blackstone, A. (2012). Sexual harassment, workplace authority, and the paradox of power. American Sociological Review 77(4): 625-647.

National Research Council (2004). Measuring Racial Discrimination. Washington: The National Academies Press.

Portal China.org.pl (2011). 20\% Women Sexually Harassed in Workplace, http://www.china.org. cn/china/2011-05/04/content_22489271.htm.

RPO (2018). Doświadczenie molestowania wśród studentek i studentów. Analiza i zalecenia. Warszawa.

Sandroff, R. (1988). Sexual harassment in the Fortune 500 Working Woman 12: 69-73.

Szwiec, P. (2006). Molestowanie seksualne w miejsce pracy. Zarządzanie Zasobami Ludzkimi 5: $25-37$.

Warylewski, J. (1999). Molestowanie seksualne w miejscu pracy. Sopot.

ZUS (2019a). Absencja chorobowa w 2018 r. Warszawa.

ZUS (2019b). Wydatki na świadczenia z ubezpieczeń społecznych związane z niezdolnością do pracy w 2018 roku. Warszawa. 


\section{SEXUAL HARASSMENT \\ AND ITS FINANCIAL COSTS TO THE ECONOMY}

S u m m a r y

The main goal of the paper is to consider the complex and interdisciplinary issue of sexual harassment as a phenomenon in the labour market, in economic terms, with regard to its effects on work and wages. The spatial scope covers Poland, with reference to China, the United Kingdom, Sweden and the US. The time range refers to the years 2007-2018. The hypothesis put forward in the article is as follows: sexual harassment in the workplace contributes to measurable financial costs, the reduction of which could make a real contribution to achieving a higher level of gross domestic product. First, the concept and forms of sexual harassment are outlined, as well as the impact this phenomenon has on the possibility of other types of economic discrimination occurring. The next section presents an analysis of the available results of public opinion surveys on the scope and economic impact of the researched phenomenon in Poland, China and the US. Finally, the deductive and inductive methods for measuring sexual harassment with regard to the UK, Sweden and the US are scrutinised, and attempts are made to estimate the cost of sexual harassment for Poland in 2018.

Keywords: sexual harassment; financial costs; labour market; workplace 